\title{
Correction to: Nuclear phylogeography of the temperate tree species Chiranthodendron pentadactylon (Malvaceae): Quaternary relicts in Mesoamerican cloud forests
}

\author{
Diana Gabriela Hernández-Langford ${ }^{1 *}$, María Elena Siqueiros-Delgado ${ }^{1}$ and Eduardo Ruíz-Sánchez²
}

\section{Correction to: BMC Evolutionary Biology (2020) 20:44 https://doi.org/10.1186/s12862-020-01605-8}

Following publication of the original article [1], the authors notified us that the legend for Fig. 1 is incorrect (the order of the names is misplaced). The correct legend is presented below:

Fig. 1 STRUCTURE bar plot showing the individual membership coefficients assigned to each $\mathrm{K}$ number of groups $(K=2)$ defined as populations. The individuals are classified according to their sampling site: 1 ) Carrizal de Bravo, Guerrero. (2) San Mateo Río Hondo, Oaxaca. (3) Motozintla, Chiapas. (4) Tacaná volcano, Chiapas. (5) San Cristóbal de las Casas, Chiapas. (6) Acatenango volcano, Chimaltenango. (7) Chimaltenango Quetzaltenango. (8) Totonicapán. (9) Sierra de los Cuchumatanes, Huehuetenango.

\section{Author details}

'Departamento de Biología, Herbario UAA, Centro de Ciencias Básicas, Edificio 132, Universidad Autónoma de Aguascalientes, Av, Universidad No. 940, Ciudad Universitaria, 20131 Aguascalientes, Aguascalientes, México. 2Departamento de Botánica y Zoología, Centro Universitario de Ciencias, Biológicas y Agropecuarias, Universidad de Guadalajara, Camino Ing. Ramón, Padilla Sánchez 2100, Nextipac, 45200 Nextipac, Zapopan, Jalisco, México.
Published online: 31 July 2020

\section{Reference}

1. Hernández-Langford DG, et al. Nuclear phylogeography of the temperate tree species Chiranthodendron pentadactylon (Malvaceae): Quaternary relicts in Mesoamerican cloud forests. BMC Evol Biol. 2020;20:44. https://doi.org/10. 1186/s12862-020-01605-8.

The original article can be found online at https://doi.org/10.1186/s12862020-01605-8

*Correspondence: digahela.87@gmail.com

'Departamento de Biología, Herbario UAA, Centro de Ciencias Básicas, Edificio 132, Universidad Autónoma de Aguascalientes, Av, Universidad No. 940, Ciudad Universitaria, 20131 Aguascalientes, Aguascalientes, México Full list of author information is available at the end of the article

(c) The Author(s). 2020 Open Access This article is licensed under a Creative Commons Attribution 4.0 International License, which permits use, sharing, adaptation, distribution and reproduction in any medium or format, as long as you give appropriate credit to the original author(s) and the source, provide a link to the Creative Commons licence, and indicate if changes were made. The images or other third party material in this article are included in the article's Creative Commons licence, unless indicated otherwise in a credit line to the material. If material is not included in the article's Creative Commons licence and your intended use is not permitted by statutory regulation or exceeds the permitted use, you will need to obtain permission directly from the copyright holder. To view a copy of this licence, visit http://creativecommons.org/licenses/by/4.0/ The Creative Commons Public Domain Dedication waiver (http://creativecommons.org/publicdomain/zero/1.0/) applies to the data made available in this article, unless otherwise stated in a credit line to the data. 